\title{
Microseismic Signals in Heading Face of Tengdong Coal Mine and Their Application for Rock Burst Monitoring
}

\author{
JianJu Ren $\mathbb{D}^{1},{ }^{1}$ Wenlong Zhang $\mathbb{D},{ }^{1}$ Zheng Wu, ${ }^{1} \mathrm{Ji} \mathrm{Li}^{2}$ and Ying Shen ${ }^{3}$ \\ ${ }^{1}$ School of Energy and Mining Engineering, China University of Mining and Technology (Beijing), Beijing 10083, China \\ ${ }^{2}$ School of Energy, Xi'an University of Science and Technology, Xi'an 710054, China \\ ${ }^{3}$ Longmenxia South Coal Mine of Sichuan Huayingshan Coal Industry Co., Ltd., Guangan 638020, China
}

Correspondence should be addressed to JianJu Ren; 171576375@qq.com

Received 29 November 2020; Revised 11 January 2021; Accepted 19 January 2021; Published 29 January 2021

Academic Editor: Guangchao Zhang

Copyright ( $\odot 2021$ JianJu Ren et al. This is an open access article distributed under the Creative Commons Attribution License, which permits unrestricted use, distribution, and reproduction in any medium, provided the original work is properly cited.

Microseismic (MS) monitoring is an important and commonly used geophysical method in coal mines to predict rock burst which has great influence on safety production. MS monitoring technology and analysis method of the whole mine or working face have been matured, but its use in heading faces of coal mine is not mature due to small disturbances and narrow layout spaces. To carry out MS monitoring and early warning in the heading face, signal recognition must be adequately performed first, and monitoring objects and indicators must be obtained. Through field tests of MS systems at the 117 track gateway of Tengdong coal mine, interference signals of equipment operation and effective signals of coal vibration are accurately collected. After analysis, the waveform characteristics, spectrum, and propagation distance of the interference signals and coal vibration signal are different. Some effective signals with small energy (one-channel triggering) cannot be used as early warning indicators because they are concealed by interference signals. Through trial operation, it is found that large energy (three-channel and four-channel triggering) coal vibration events successfully predicted a rock burst. The MS system of 117 track gateway of Tengdong coal mine should be able to remove the interference signals in real time through the algorithm and take the number of large energy coal vibration signal rather than all coal vibration events as the predictor for rock burst risk monitoring.

\section{Introduction}

MS monitoring, as an important and commonly used geophysical method, has been applied in many fields, such as earthquakes [1-5], hydropower stations [6-8], metal mines [9-12], tunnels $[13,14]$, petroleum engineering projects $[15,16]$, hydraulic or pneumatic fracturing [17-19], and coal mines [20-23]. MS has achieved good results. Among these fields, coal mines are more widely monitored by MS systems. The main type of MS monitoring systems used in coal mines includes regional monitoring [24-26] and local monitoring. Regional monitoring has a large (usually greater than $500 \mathrm{~m}$ ) spacing between measurement points and aims to monitor the whole mine, while the spacing between points in local monitoring is smaller (usually less than $200 \mathrm{~m}$ ) and aims at specific mining areas (for example, working face [27-29] and heading face). In the field of rock burst monitoring, monitoring technology and analysis method of working face have been matured, but research on MS monitoring in heading faces is not mature due to small disturbances and narrow layout spaces.

With the increase in mining depth, the early warning, prevention, and control of rock burst is becoming more and more difficult. Rock burst accidents occurred frequently, and many of these accidents occurred in heading face [30-32]. Here, we count the number of rock burst accidents in five mines of Yima Coalfield in China over the past five years. Results show that 44 of the 108 counted accidents occurred in the heading face, accounting for $40.74 \%$ (Figure 1). The monitoring and prevention of rock burst in heading face is imminent, but in practical application, it mainly reflected as follows: (1) the disturbance of heading face is small, and the conventional techniques such as stress monitoring and anchor cable force measurement have little change in 


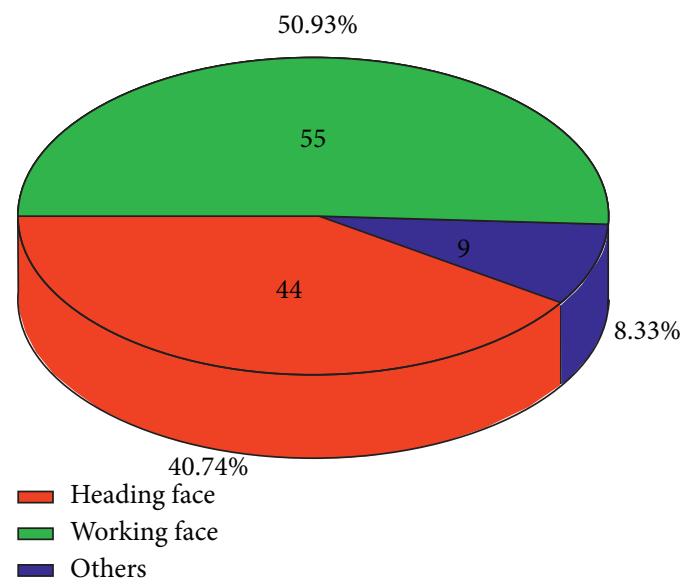

Figure 1: Place of rock burst accidents occurrence in five mines of Yima Coalfield.

numerical value, which results in poor monitoring and early warning effect [33]. (2) MS monitoring is the main technology of early warning of rock burst in coal mine, but it has not been used in early warning of rock burst in heading face. The main problem is that the construction environment of heading face is very complex. There are roadheader, loader, belt conveyor, roofbolter, and other machinery. The vibration of these machines is large, and the effective coal vibration (CV) signals may be concealed by them. (3) Under the comprehensive excavation technology, the excavation speed of heading face is faster (more than $12 \mathrm{~m}$ per day), and the distance between monitoring points should not be too small; otherwise, the amount of group shifting engineering will be increased when real-time online MS monitoring is used.

In this paper, the waveforms of interference signals and effective CV signals are obtained through field records and MS system data of 117 track gateway of Tengdong coal mine (117 TGTC), and the waveform characteristics of the signals are analyzed and distinguished by means of waveform and spectral analyses. This study provides a basis for the selection of monitoring objects and indicators, threshold setting of trigger acquisition, and measurement point layout of the online MS system in 117 TGTC.

\section{Field Test and Experiment}

The Tengdong coal mine is located in Tengzhou City, Shandong Province, China. The No. 3 coal seam with an average thickness of $7.37 \mathrm{~m}$ is one of the target coal seams. The average depth of the No. 3 coal seam is $830 \mathrm{~m}$, and its rock burst tendency is weak.

117 TGTC is connected to the ground through the main roadway and shaft, as shown in Figure 2(a). The width and height of 117 TGTC are $4.4 \mathrm{~m}$ and $3.4 \mathrm{~m}$, respectively. The 117 TGTC is supported by rebar bolt and cable bolt, as shown in Figure 2(b). The direct roof is sandstone with an average thickness of $17.94 \mathrm{~m}$. The 117 TGTC drives along the floor of the No. 3 coal seam and adopts the fully mechanized excavation mode, which is divided into two sequential working procedures: excavation and support. The excavation process is completed by a fully mechanized roadheader followed by a loader and a belt conveyor. The supporting process is drilled and compressed by a roofbolter.

The MS system used in the field test includes four sensors, one acquisition instrument, and one server with corresponding software. The system collects vibration signals and converts them into electrical signals. Then, the signals are transmitted to the ground server through a transmission cable, as shown in Figure 3. The acquisition frequency is $2000 \mathrm{~Hz}$, and the sensor receiving frequency is $0-800 \mathrm{~Hz}$. To avoid missing waveform data in the initial trigger acquisition settings, a continuous acquisition mode is adopted during the field test, and the storage time of each waveform is $5 \mathrm{~s}$. It is difficult to deploy measurement points in space due to the single heading of the gateway, so four sensors are arranged in a straight line and installed to the tail of the roof rebar bolt of 117 TGTC. The spacing of the four sensors (the order from front to back is \#1, \#2, \#3, and \#4) is $55 \mathrm{~m}$. The distance between the \#1 sensor and heading face is $15 \mathrm{~m}$. After arrangement of the MS system is finished, the bottom noise waveform of the MS system is tested first, and then, the precise running time of various equipment and occurrence time of $\mathrm{CV}$ (CV signals are recorded by sound that emits at the same time) is recorded in detail. The running records of the equipment mainly include drilling operation of the roofbolter, compressing blot operation of the roofbolter, running time of the belt conveyor, and running time of the roadheader.

\section{Results and Discussion}

According to the running time of the equipment and the occurrence time of $\mathrm{CV}$, the corresponding time of received waveforms is found. Four kinds of interference signals and one kind of effective CV signal are obtained and analyzed in detail below. In addition, the maximum amplitude (MA) of the bottom noise of the MS system is $40 \mathrm{mV}$.

\subsection{Waveform and Spectrum of Roofbolter Drilling Operation.} The drilling operation of the roofbolter only affected the \# 1 sensor, showing that the propagation distance of the interference signal is greater than $15 \mathrm{~m}$ (distance to \#1 sensor) 


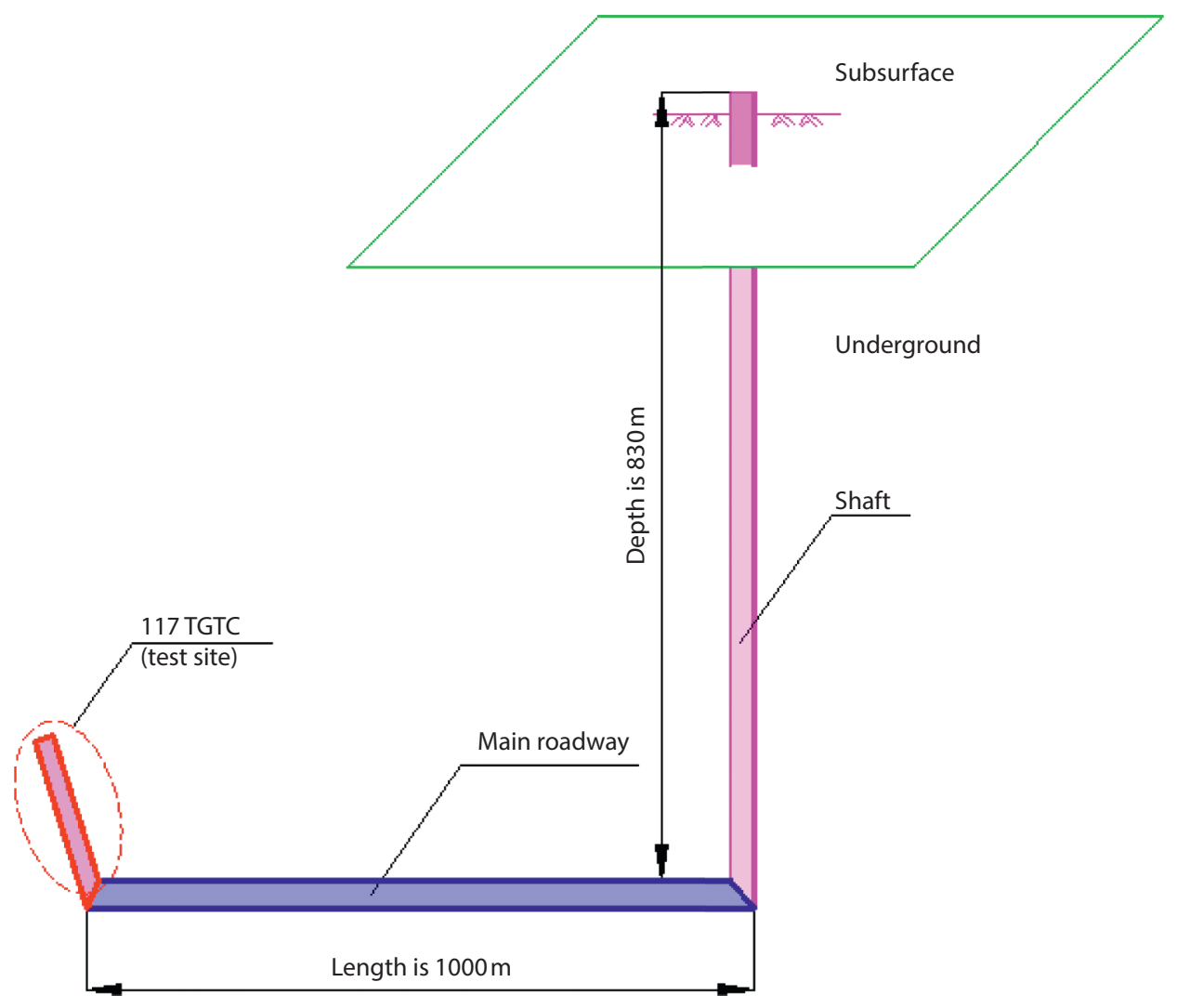

(a)

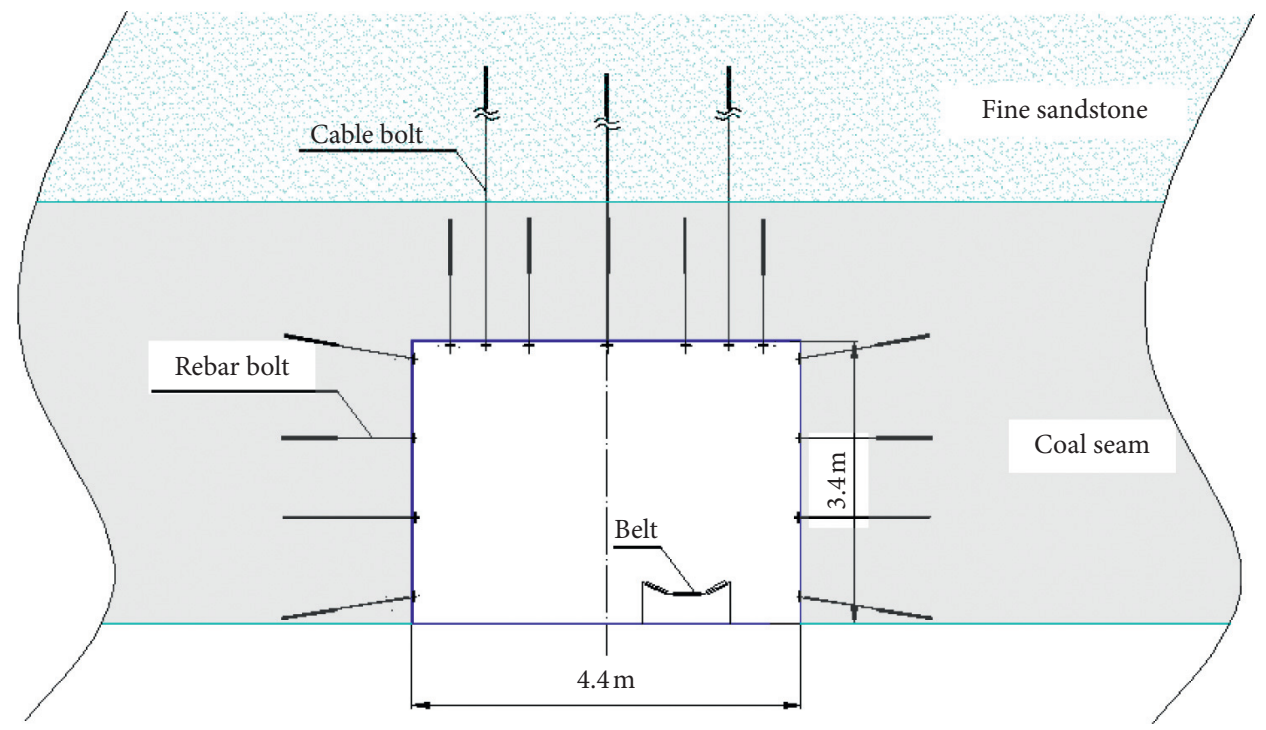

(b)

FIGURE 2: Basic situation of 117 TGTC: (a) location sketch; (b) section. 


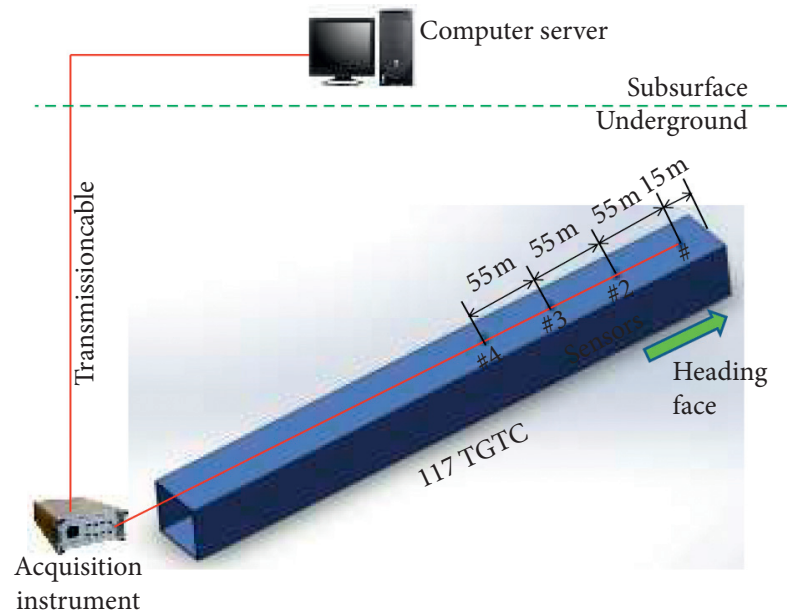

Figure 3: MS system used in 117 TGTC.

but less than $70 \mathrm{~m}$ (distance to \#2 sensor). The signal waveform is shown in Figure 4. The waveform characteristics of the roofbolter are obvious. A bulge waveform with an MA of approximately $100 \mathrm{mV}$ appears every second or two, and the start point is very obvious, which occurred at approximately $4 \mathrm{~s}$ in Figure 4(a).

Figure 5 is the signal spectrum of Figure 4(b), Figure 5(a) is the signal spectrum, and Figure 5(b) is the time spectrum of the signal. Signal spectrum can clearly indicate the main frequency of the signal [34]. However, the time spectrum can provide the change in the main frequency of the signal with time. If the main frequency of the signal always exists in the time window, it indicates that the interference is persistent or throughout the interference process. Otherwise, if the interference exists only in a period of the machinery's running time, it is indicated as the partial interference of the machinery. This method has been used in $[19,35]$. From Figure 5(a), it can be seen that there are three main frequencies, which are $76 \mathrm{~Hz}, 347 \mathrm{~Hz}$, and $467 \mathrm{~Hz}$, during the drilling process of the roofbolter. The amplitudes of the three main frequencies are all approximately $4 \mathrm{mV}$. Figure 5(b) indicates that a $76 \mathrm{~Hz}$ frequency always exists in the drilling process, while $347 \mathrm{~Hz}$ and $467 \mathrm{~Hz}$ frequencies only exist in the bulge waveform section. The results show that $76 \mathrm{~Hz}$ interference frequency should be the continuous interference generated by belt operation, while $347 \mathrm{~Hz}$ and $467 \mathrm{~Hz}$ exist only in period of "bulge waveform."

\subsection{Waveform and Spectrum of Compressing Bolt Operation.} The compressing bolt operation of the roofbolter only affected the \#1 sensor and showed that the propagation distance is greater than $15 \mathrm{~m}$ (distance to $\# 1$ sensor) but less than $70 \mathrm{~m}$ (distance to \#2 sensor). As shown in Figure 6, the start point of compression is clearly at $1.4 \mathrm{~s}$ in Figure 6(a), and the MA increases gradually from $40 \mathrm{mV}$ of bottom noise to $240 \mathrm{mV}$. During the compaction process, the MA remains at $240 \mathrm{mV}$, and after the compression process, the amplitude gradually decreases to the bottom noise amplitude.
Figure 7 is the signal spectrum of Figure 6(b), where Figure $7(a)$ is the signal spectrum and Figure $6(\mathrm{~b})$ is the time spectrum of the signal. From Figure 7(a), it can be seen that the main frequency is between $192 \mathrm{~Hz}$ and $255 \mathrm{~Hz}$ during the roofbolter compression bolt process. The amplitude of the main frequency is approximately $20 \mathrm{mV}$. Figure 7 (b) indicates that the main frequency always exists in the drilling process.

3.3. Waveform and Spectrum of Belt Conveyor Working Operation. The belt conveyor start and working operation waveform of the \#1 sensor is shown in Figure 8. Only the belt conveyor is working during this period of time (belt conveyor should be opened first, and other equipment, including the roadheader, are opened later). The start point of compression is clearly at $1.2 \mathrm{~s}$ in Figure 8(a), and the MA increases gradually from $40 \mathrm{mV}$ of bottom noise to $110 \mathrm{mV}$. Figure $8(\mathrm{~b})$ is the signal spectrum, and Figure $8(\mathrm{c})$ is the time spectrum of the signal. From Figure $8(\mathrm{~b})$, it can be seen that the main frequency is between $193 \mathrm{~Hz}$ and $247 \mathrm{~Hz}$ during the belt conveyor working process. The amplitudes of $193 \mathrm{~Hz}$ and $247 \mathrm{~Hz}$ are approximately $13 \mathrm{mV}$ and $7 \mathrm{mV}$, respectively. Figure 8(c) indicates that the $193 \mathrm{~Hz}$ and $247 \mathrm{~Hz}$ frequencies always exist in the working process. In the course of the belt conveyor working operation, the amplitude of the \#2 sensor does not increase. The reason may be that the \#1 sensor is affected by the greater vibration of the head of the belt conveyor, while the belt itself will not cause the amplitude of the sensor to exceed the bottom noise value of $40 \mathrm{mV}$.

3.4. Waveform and Spectrum of the Roadheader Working Operation. The roadheader working operation waveform of the \#1 sensor is shown in Figure 9(a). The MA of the roadheader working process (belt conveyor is working at the same time) is $380 \mathrm{mV}$. Figure 9 (b) is the signal spectrum, and Figure $9(c)$ is the time spectrum of the signal. From Figure 9(b), it can be seen that the main frequency is between 


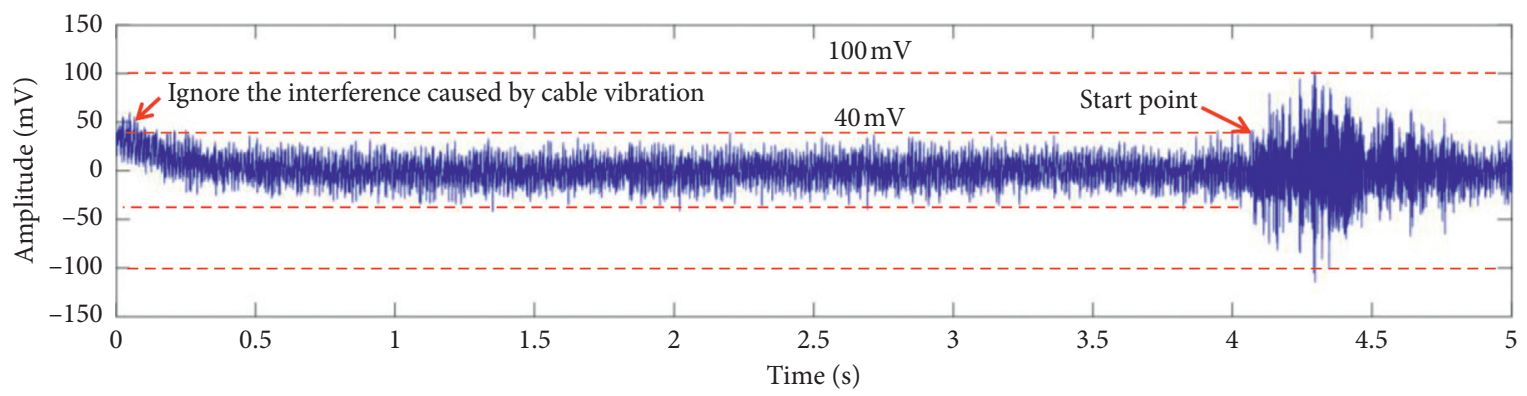

(a)

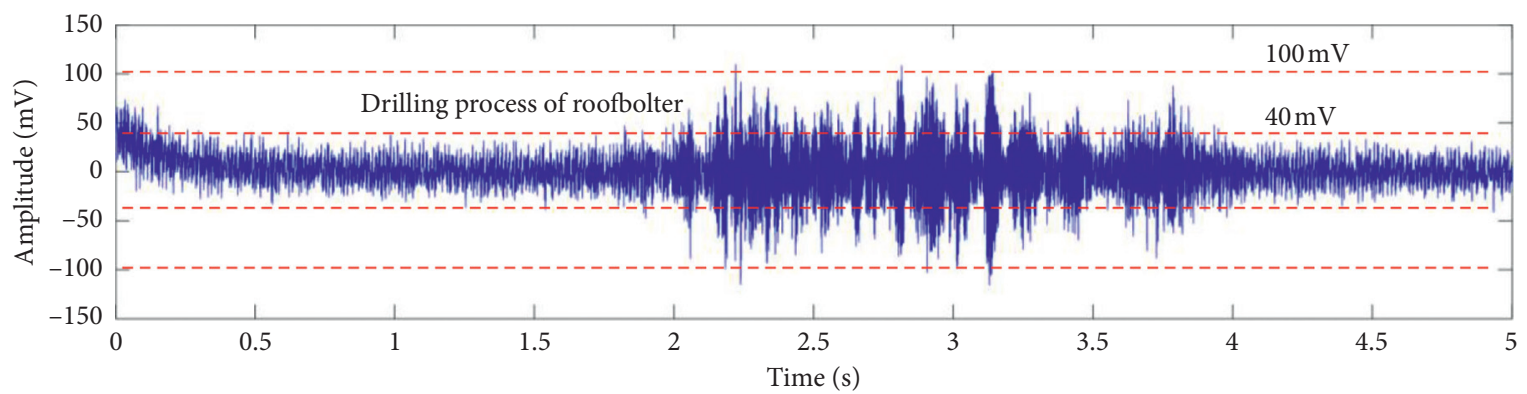

(b)

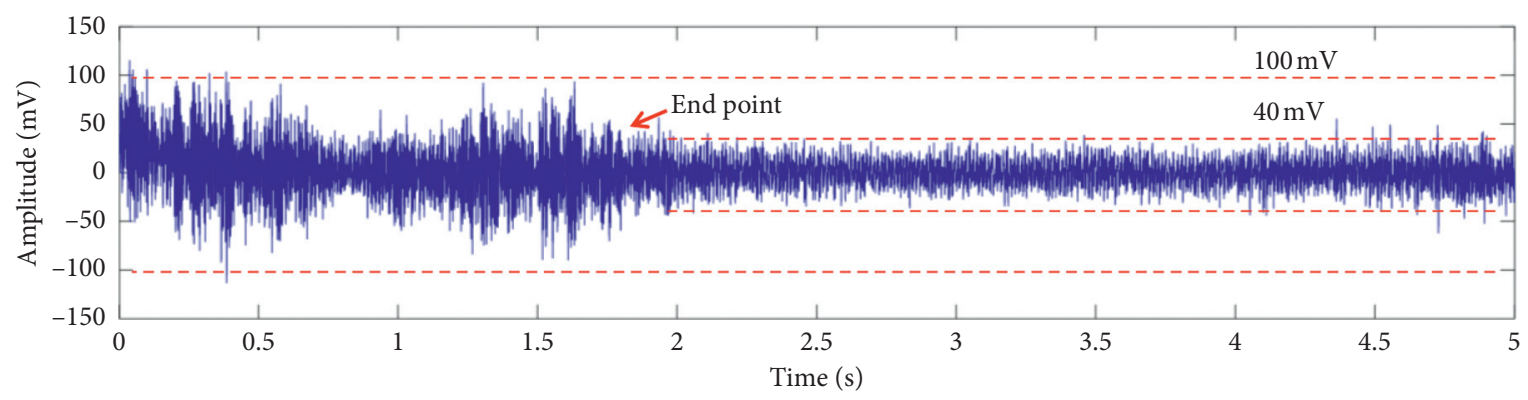

(c)

FIgURE 4: Waveform characteristics of roofbolter drilling operation: (a) 0-5 s; (b) 5-10 s; (c) 10-15 s.

$193 \mathrm{~Hz}$ and $247 \mathrm{~Hz}$ during the roadheader working process. The main frequency value is the same as when the belt conveyor works alone, but the corresponding amplitude increases from approximately $13 \mathrm{mV}$ and $7 \mathrm{mV}$ to approximately $22 \mathrm{mV}$ and $26 \mathrm{mV}$. Figure 9(c) indicates that the $193 \mathrm{~Hz}$ and $247 \mathrm{~Hz}$ frequencies always exist in the working process. As the roadheader worked, the amplitude of the \#2 sensor increased to $80 \mathrm{mV}$, showing that the propagation distance of the interference signal was greater than $70 \mathrm{~m}$ (distance to \#2 sensor) but less than $125 \mathrm{~m}$ (distance to \#3 sensor).

3.5. Waveform Characteristics and Propagation Analysis of the $\mathrm{CV}$ Signal. In this field test, $9 \mathrm{CV}$ signals are recorded when the equipment is not running. The MA of the CV signal is varying from $238 \mathrm{mV}$ to $7914 \mathrm{mV}$. According to onsite questioning of the construction personnel in 117 TGTC, the CV signal mainly occurs from two sides of the gateway without support and from the front of 117
TGTC. The propagation distance of the CV signal directly affects the arrangement of the MS measurement points. The MA and propagation distance of the $\mathrm{CV}$ signals are shown in Table 1 . When the MA received by the \#1 sensor is $7914 \mathrm{mV}, 6269 \mathrm{mV}$, and $2022 \mathrm{mV}$, they lead to a four-channel triggering $\mathrm{CV}$ event, which shows that the propagation distance exceeds $180 \mathrm{~m}$ (distance to the \#4 sensor). When the MA received by the \# 1 sensor is $1799 \mathrm{mV}$ and $1232 \mathrm{mV}$, they cause a three-channel triggering $\mathrm{CV}$ event, which indicates that the propagation distance is greater than $125 \mathrm{~m}$ (distance to \#3 sensor) but less than $180 \mathrm{~m}$. When the MA received by the \#1 sensor is $1029 \mathrm{mV}$ and $687 \mathrm{mV}$, they cause a two-channel triggering $\mathrm{CV}$ event, which indicates that the propagation distance is greater than $70 \mathrm{~m}$ (distance to \#2 sensor) but less than $125 \mathrm{~m}$. When the MA received by the \#1 sensor is $346 \mathrm{mV}$ and $238 \mathrm{mV}$, a one-channel triggering $\mathrm{CV}$ event occurs, which indicates that the propagation distance is greater than $15 \mathrm{~m}$ (distance to \# 1 sensor) but less than $70 \mathrm{~m}$. 


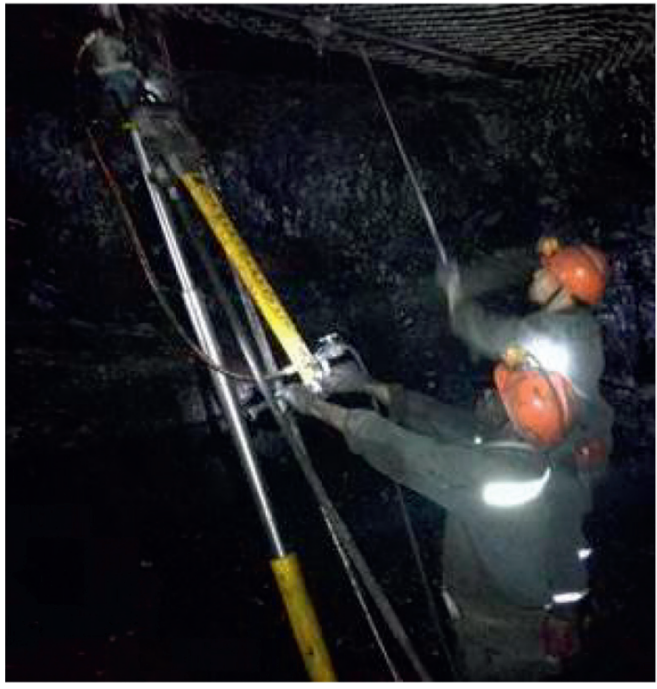

Drilling process of roofbolter

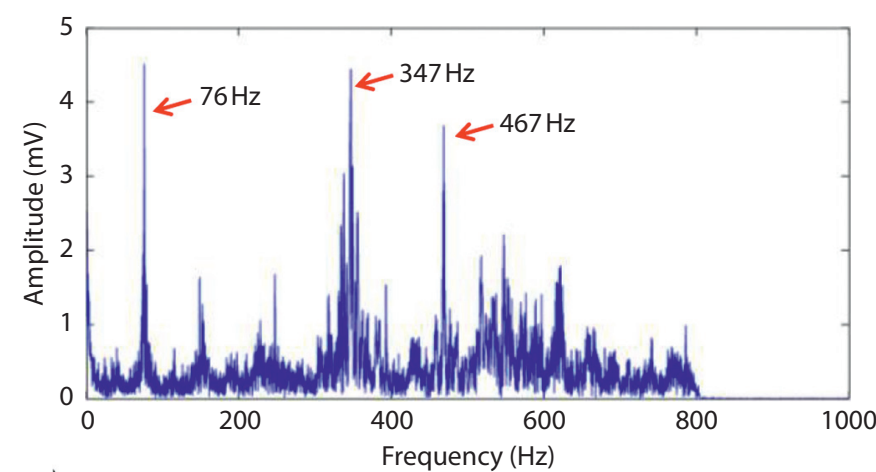

(a)

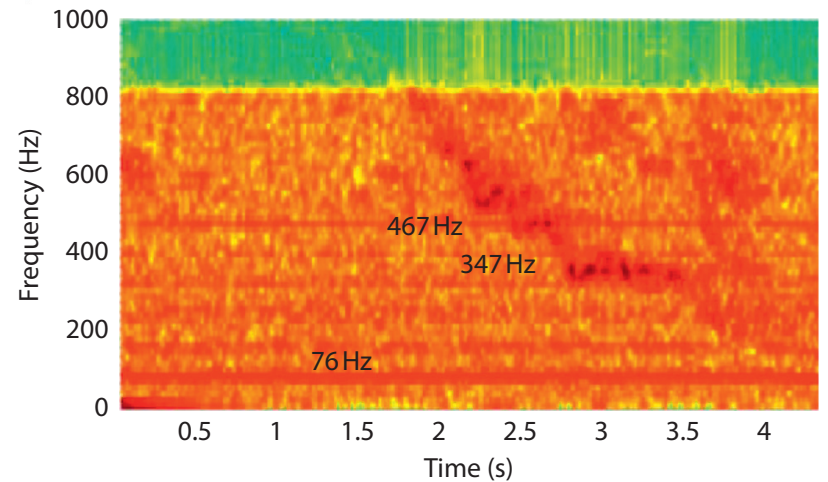

(b)

FIgURE 5: Spectrum of roofbolter drilling process: (a) spectrum of Figure 4(b); (b) time spectrum of Figure 4(b).

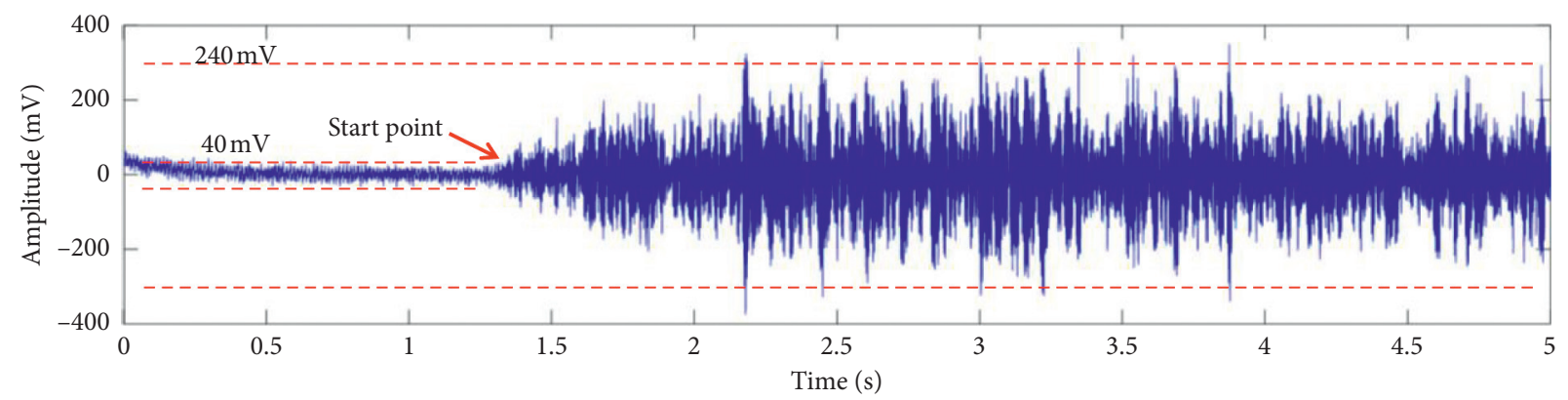

(a)

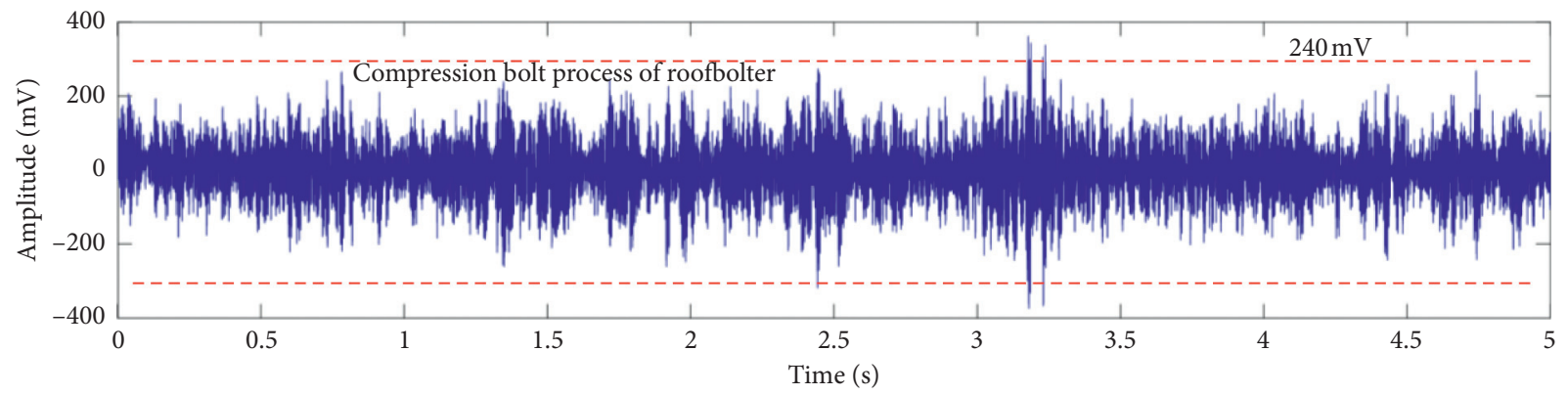

(b)

Figure 6: Continued. 


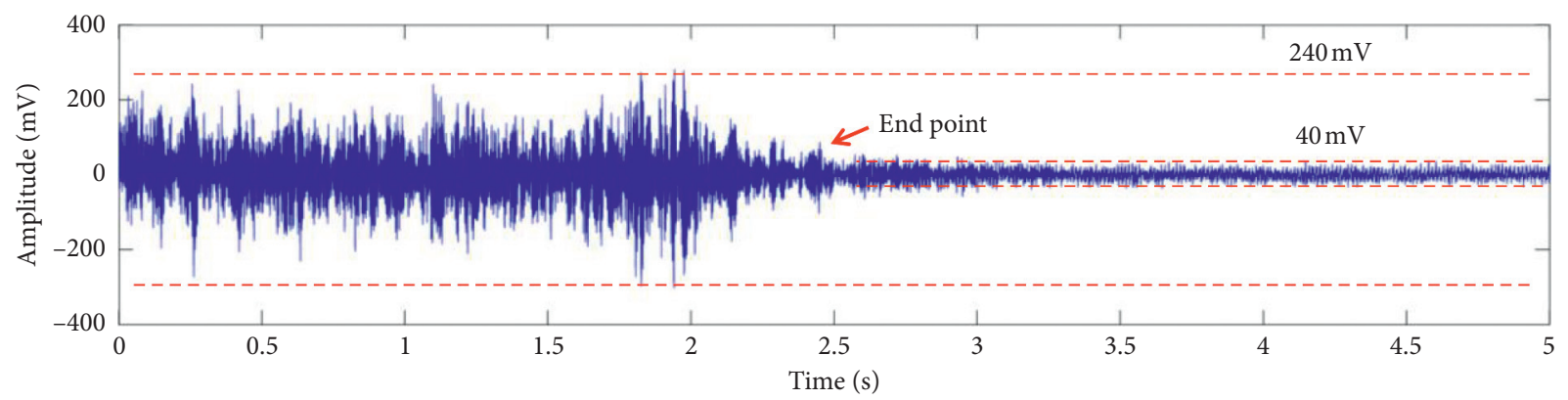

(c)

Figure 6: Waveform characteristics of roofbolter compression bolt operation: (a) 0-5s; (b) 5-10 s; (c) 10-15s.

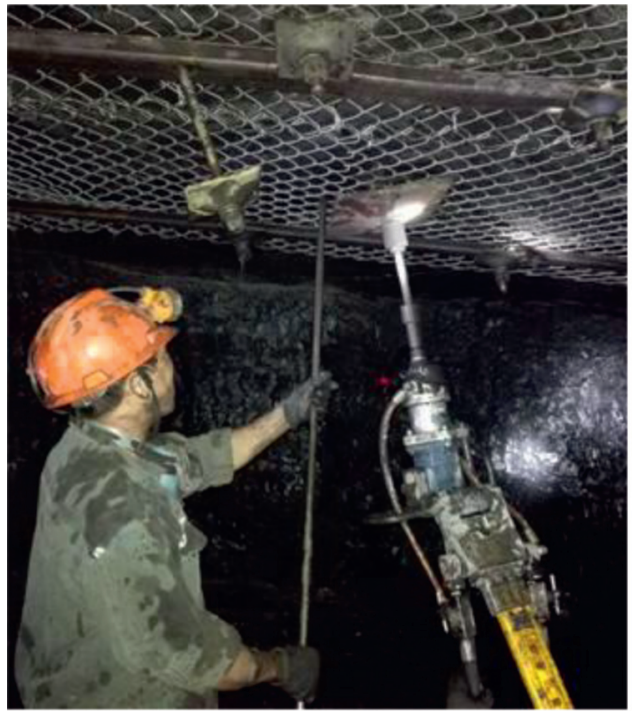

Compressing bolt process of roofbolter

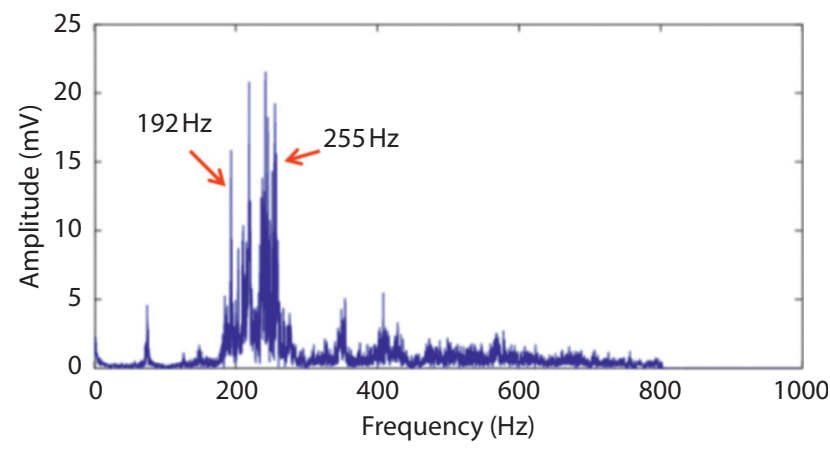

(a)
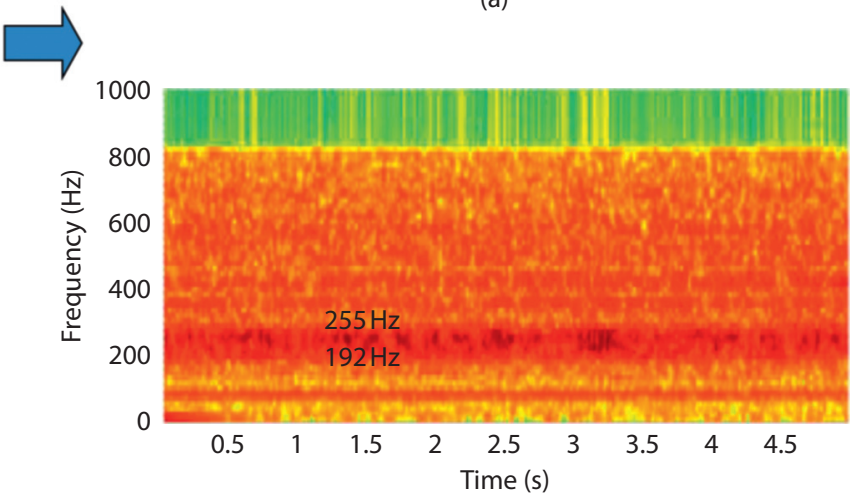

(b)

Figure 7: Spectrum of roofbolter drilling process: (a) spectrum of Figure 6(b); (b) time spectrum of Figure 6(b).

Select one CV signal with an MA of $6269 \mathrm{mV}$ (\#1 sensor) for detailed analysis (see Figure 10). The MAs of the \#1, \#2, \#3, and \#4 sensors are $6269 \mathrm{mV}, 2405 \mathrm{mV}, 1532 \mathrm{mV}$, and $503 \mathrm{mV}$, respectively. The waveform of the \#1 sensor is particularly easy to pick up at the take-off point, the arrival time of the \#1 sensor (T1) is $0.201 \mathrm{~s}$, and the arrival time of the \#2 (T2) and \#3 (T3) sensors is difficult to pick up, which are $0.223 \mathrm{~s}$ and $0.243 \mathrm{~s}$, respectively, while the take-off point of the \#4 sensor is especially unclear and cannot be picked up. As shown, the farther the distance is, the harder it is to pick up the take-off point. By dividing the distance $(\triangle S=55 \mathrm{~m})$ by the time difference (taking the mean of $\triangle \mathrm{T} 12$ and $\triangle \mathrm{T} 23$ results in $\triangle T=0.021 \mathrm{~S}$ ), a simple calculation of the coal seam velocity of 117 TGTC can be obtained, which is $\triangle \mathrm{S} / \triangle T=2619 \mathrm{~m} / \mathrm{s}$. At the same time, occurrence location of the CV event can be positioned roughly. The amplitudes of MS signals decrease gradually from \#1 sensor to \#4 sensor and arrival time is getting bigger and bigger, indicating that the CV event occurred in front of the \#1 sensor (happened around the heading face).

Figure 11(a) is the three-dimensional amplitude spectra of the \#1 sensor, showing that the main frequency of the CV signal is $60 \mathrm{~Hz}$, which is lower than the interference signals. Through filtering analysis, the MA of the CV event in different frequency 

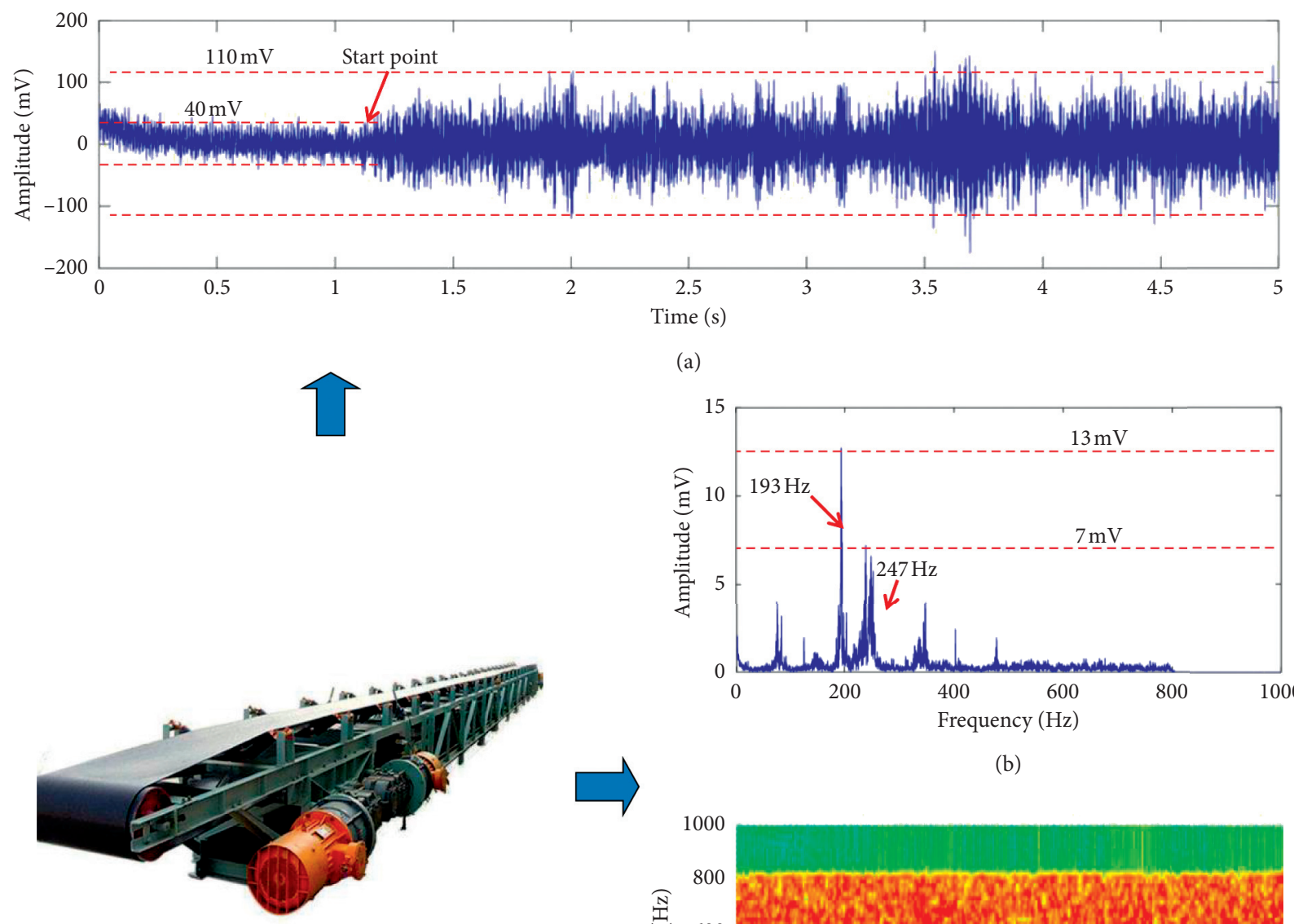

(a)

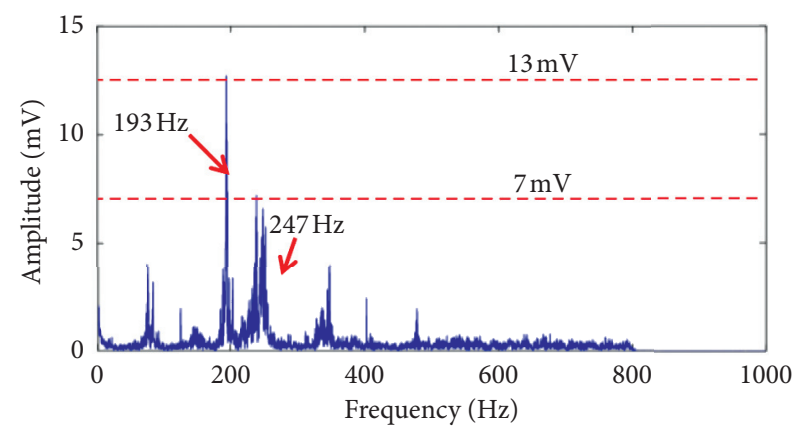

(b)

Conveyor working operation
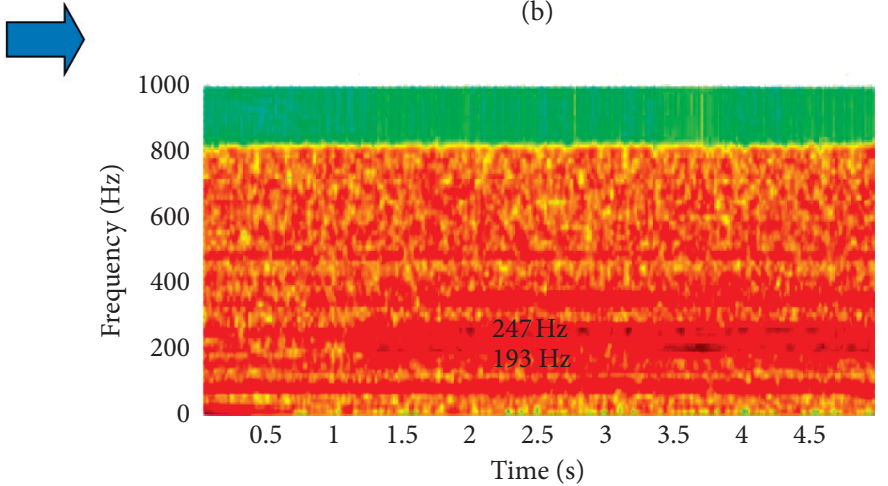

(c)

FIGURE 8: Waveform and spectrum of conveyor working process: (a) waveform; (b) spectrum of Figure 8(a); (c) time spectrum of Figure 8(a).

bands is counted, as shown in Figure 11(b). The CV signal is clearly divided into two frequency bands, a high-frequency band and a low-frequency band, and the demarcation point is $500 \mathrm{~Hz}$. The low-frequency band shows a rapid attenuation state, most of which is consistent with the attenuation trend of the original signal. The higher the frequency is, the faster the attenuation rate is. The attenuation characteristic of the high-frequency band is small, and even the MA of the rear measuring point is larger, indicating that the high-frequency signal band has not been attenuated over the distance to the \#4 sensor.

\section{Inspection of Monitoring Effect}

After obtaining the waveform characteristics and spectrum information of each interference signals, the interference waveforms are eliminated by algorithm to make the online system pick up only the effective signal as far as possible.
Under the condition of the MS system arrangement, 117 TGTC was monitored and tested online. As the test results, the signal of roadheader and drilling compaction conceals the small energy (one-channel triggering) $\mathrm{CV}$ event, but the signal exceeding the interference amplitude of roadheader is not be concealed. During the trial operation, a small rock burst occurred. The CV signals were analyzed, and no onetriggering event was found. We analyzed the two-channel triggering and above $\mathrm{CV}$ events, and the results are shown in Figure 12. It can be seen that, before the occurrence of rock burst (16-Dec), the number of four-channel triggering $\mathrm{CV}$ events increased significantly, and the number of threechannel triggering $\mathrm{CV}$ events increased slightly, while the number of two-channel triggering $\mathrm{CV}$ events did not increase, but decreased. Therefore, the number of threechannel triggering and four-channel triggering $\mathrm{CV}$ events 

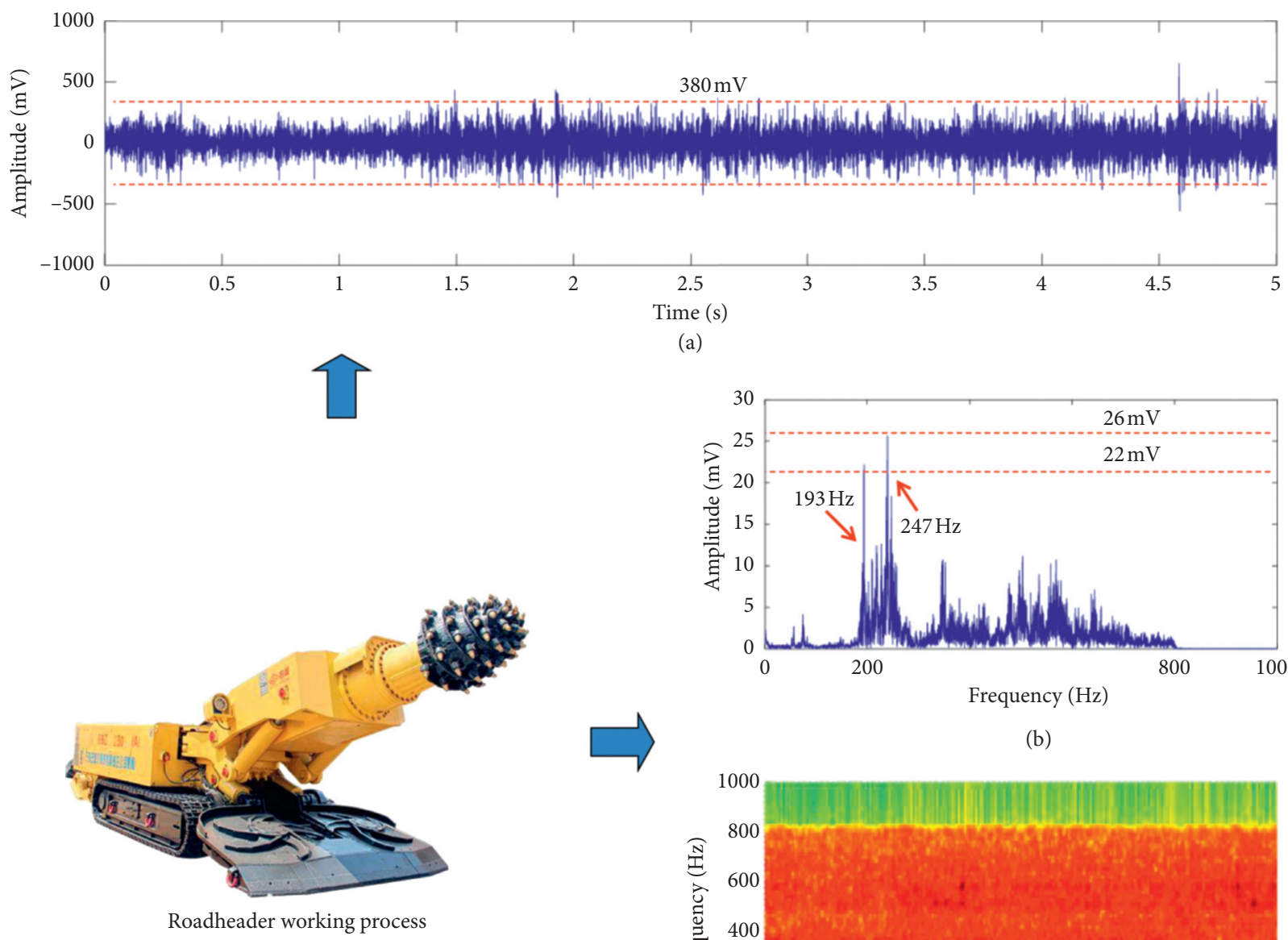

(a)

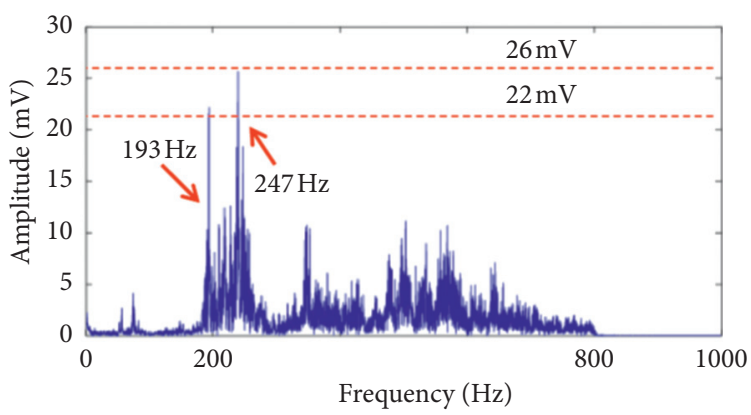

(b)

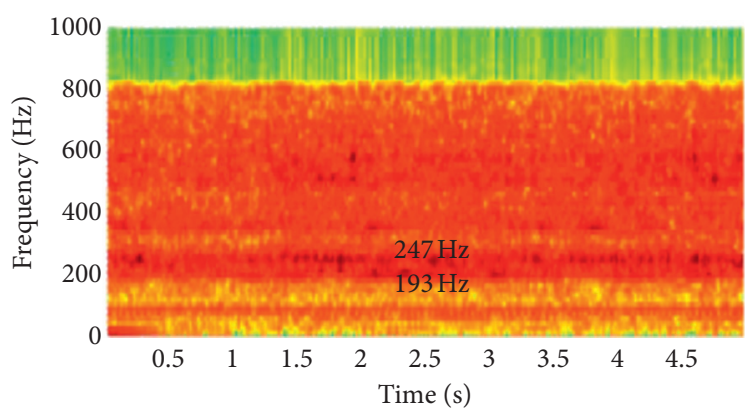

(c)

FiguRE 9: Waveform and spectrum of roadheader working process: (a) waveform; (b) spectrum of Figure 9(a); (c) time spectrum of Figure 9(a).

TABLE 1: MA and propagation distance of the CV signals.

\begin{tabular}{|c|c|c|c|c|c|c|}
\hline No. & $\begin{array}{c}\text { MA of \#1 sensor } \\
(\mathrm{mV})\end{array}$ & $\begin{array}{c}\text { MA of \#2 sensor } \\
(\mathrm{mV})\end{array}$ & $\begin{array}{c}\text { MA of \#3 sensor } \\
(\mathrm{mV})\end{array}$ & $\begin{array}{c}\text { MA of \#4 sensor } \\
(\mathrm{mV})\end{array}$ & $\begin{array}{l}\text { Number of sensors } \\
\text { received CV }\end{array}$ & $\begin{array}{l}\text { Propagation distance } \\
(\mathrm{m})\end{array}$ \\
\hline 1 & 7914 & 2329 & 961 & 240 & 4 & $>180$ \\
\hline 2 & 6269 & 2405 & 1532 & 503 & 4 & $>180$ \\
\hline 3 & 2022 & 496 & 446 & 125 & 4 & $>180$ \\
\hline 4 & 1799 & 1399 & 306 & - & 3 & $>125$ and $<180$ \\
\hline 5 & 1232 & 323 & 141 & - & 3 & $>125$ and $<180$ \\
\hline 6 & 1029 & 239 & - & - & 2 & $>70$ and $<125$ \\
\hline 7 & 687 & 172 & - & - & 2 & $>70$ and $<125$ \\
\hline 8 & 346 & - & - & - & 1 & $>15$ and $<70$ \\
\hline 9 & 238 & - & - & - & 1 & $>15$ and $<70$ \\
\hline
\end{tabular}




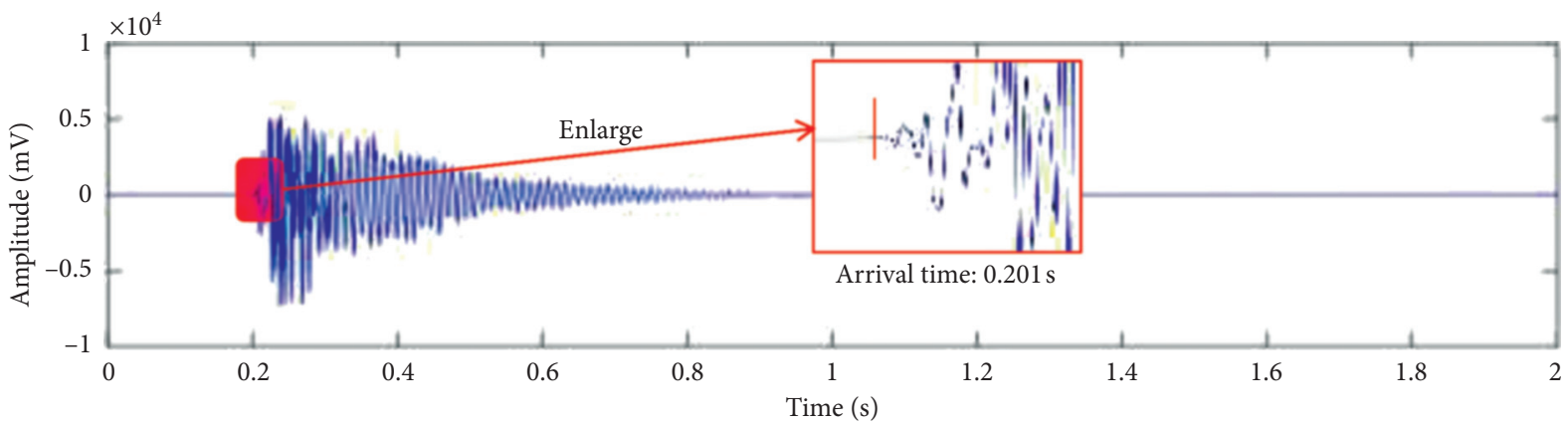

(a)

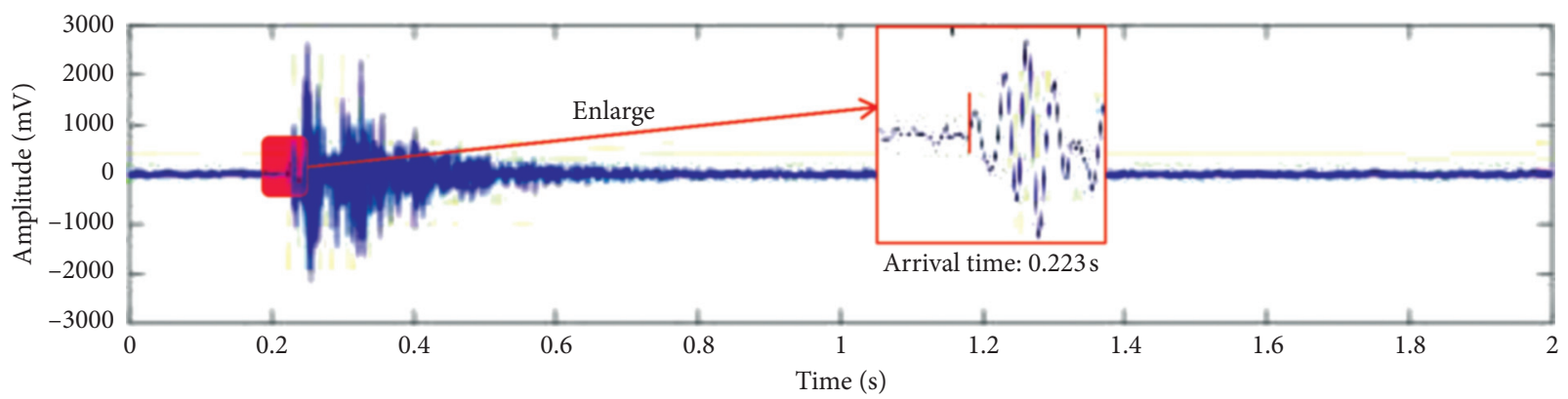

(b)

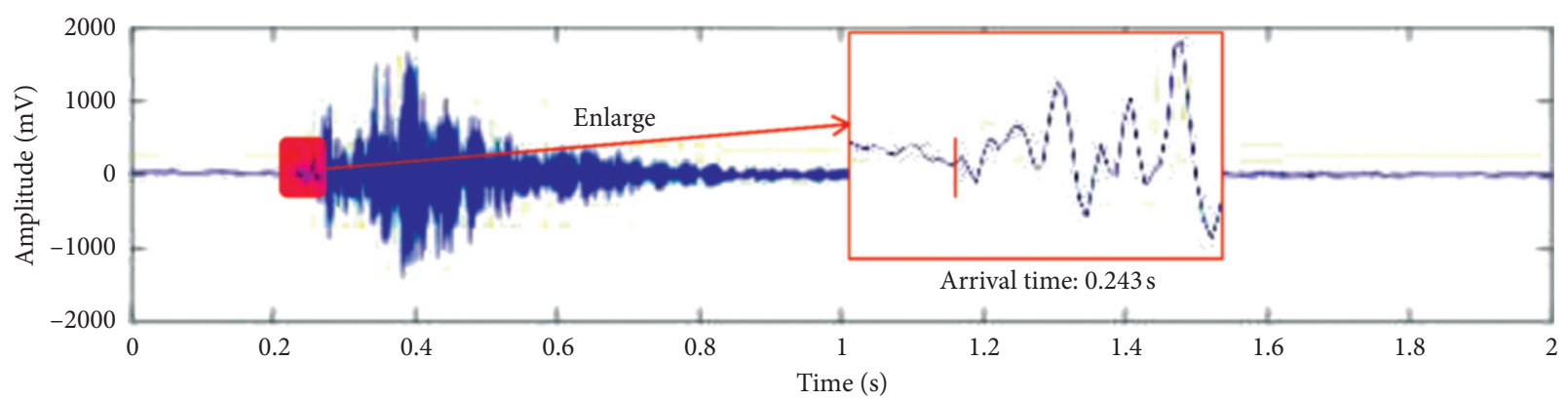

(c)

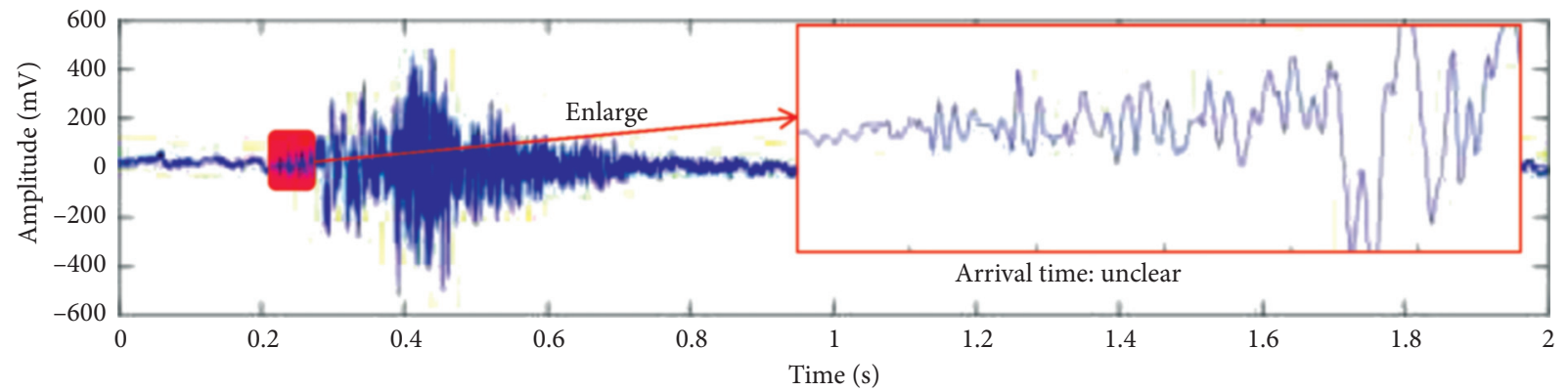

(d)

FIGURE 10: Waveform and arrival time of the CV signal: (a) waveform of \#1 sensor; (b) waveform of \#2 sensor; (c) waveform of \#3 sensor; (d) waveform of \#4 sensor. 


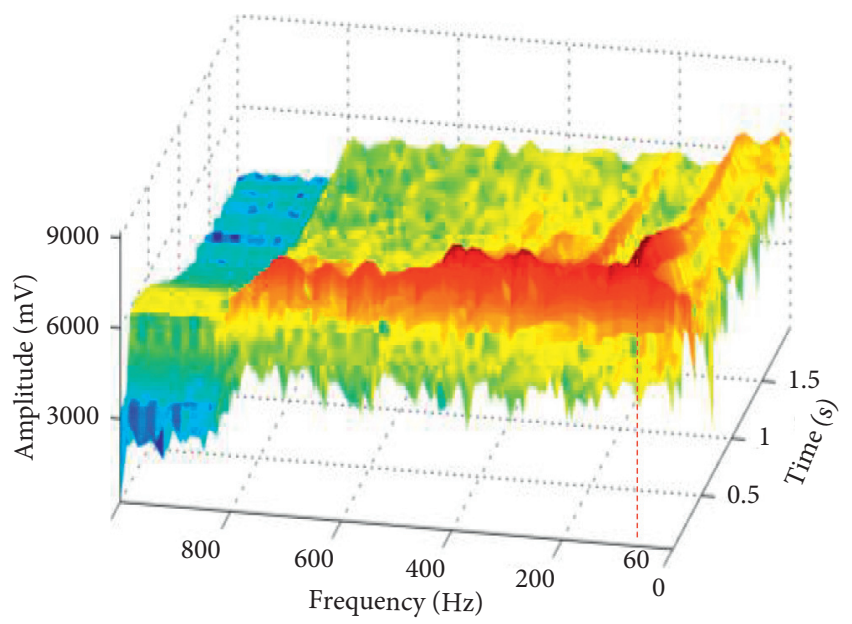

(a)

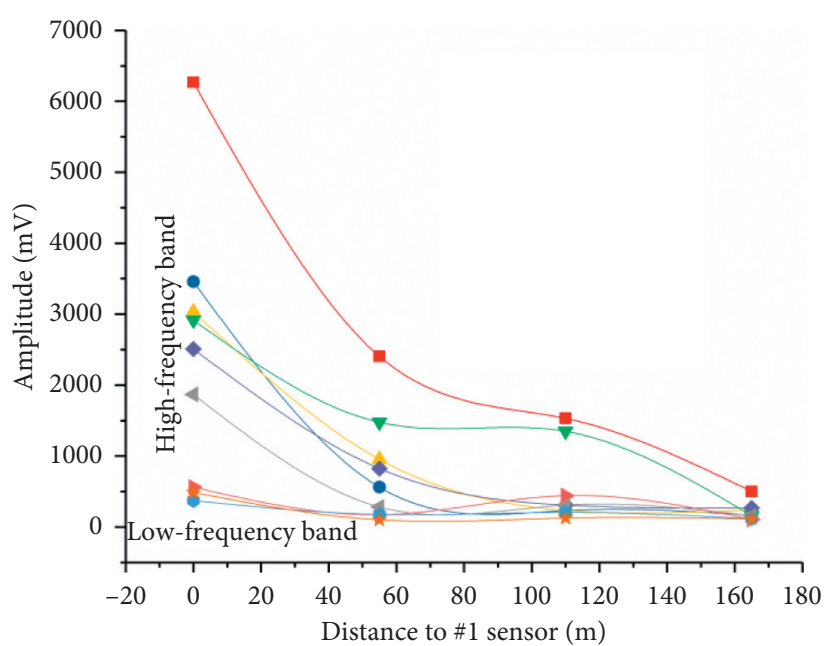

$\rightarrow-$ Original signal

$\longleftarrow 400-500 \mathrm{hz}$

$\longrightarrow 0-100 \mathrm{hz}$

$\rightarrow-500-600 \mathrm{hz}$

$-100-200 \mathrm{hz}$

$\rightarrow \quad 200-300 \mathrm{hz}$

$\rightarrow 300-400 \mathrm{hz}$

(b)

Figure 11: Analysis of selected CV signals: (a) three-dimensional amplitude spectra of the \#1 sensor; (b) attenuation of the CV signal in different frequency bands.

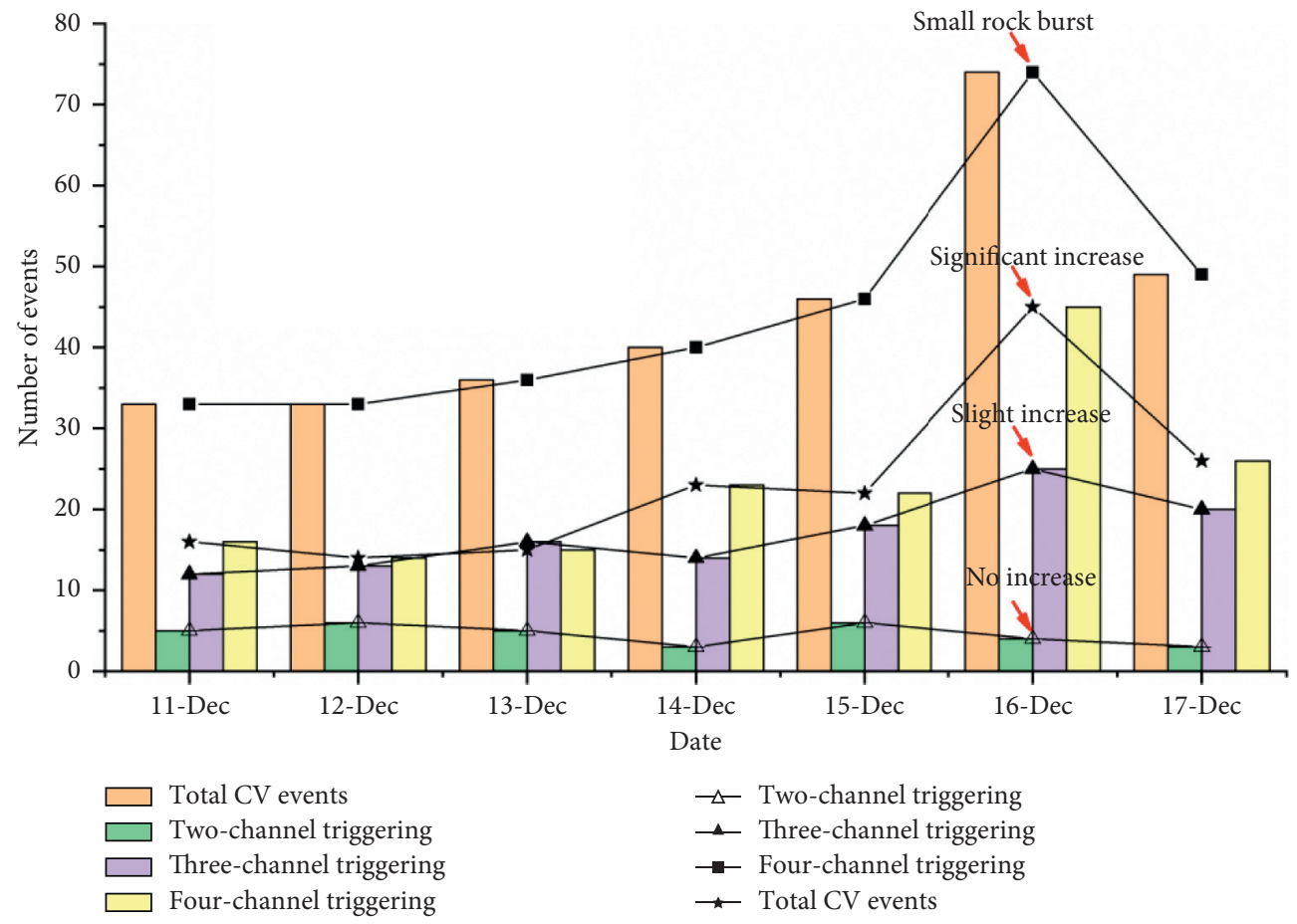

FIGURE 12: Variation curves of CV events with different triggering before rock burst. 
can be used as monitoring objects and indicators for 117 TGTC MS system.

\section{Conclusion}

Signal recognition is the primary task for monitoring and early warning of the MS system in 117 TGTC, and the interference signals should be recognized and removed in real time. Therefore, a field test of signal recognition was carried out. The waveforms of interference signals and CV signals are obtained. The interference signals include the roofbolter drilling operation signal, roofbolter compression bolt operation signal, belt conveyor working operation signal, and roadheader working process signal. The waveform characteristics, spectra, and propagation distances of the signals are analyzed. The results show that the waveform characteristics and main frequencies (or amplitude of the main frequencies) of the signals are different, and signal identification can be partly achieved by these features. Among the interference signals, the roadheader working interference signal has the largest MA of $380 \mathrm{mV}$ and the farthest propagation distance of more than $70 \mathrm{~m}$. The MA of the CV signal obtained in the field test ranges from $238 \mathrm{mV}$ to $7914 \mathrm{mV}$, showing some CV events smaller than the MA of the roadheader interference signal may be concealed. Online test shows that the number and energy level of threechannel triggering and four-channel triggering $\mathrm{CV}$ events should be used for monitoring and early warning of rock bursts, and they are obviously undisturbed by interfering signals. The field test provides a basis for triggering acquisition and measurement point arrangement of the MS system in 117 TGTC, and a new idea of rock burst monitoring index is presented in heading face.

Other rock burst monitoring areas can refer to the arrangement of the MS system and the warning index, but the equipment and geological conditions are obviously not the same as those at 117 TGTC, so before the MS system can be applied, interference signals and CV signals of the target heading face should be identified and analyzed first.

\section{Data Availability}

The data used to support the findings of this study are available from the corresponding author upon request.

\section{Conflicts of Interest}

The authors declare that there are no conflicts of interest.

\section{References}

[1] R. Will, G. El-Kaseeh, P. Jaques, M. Carney, S. Greenberg, and R. Finley, "Microseismic data acquisition, processing, and event characterization at the Illinois Basin-Decatur project," International Journal of Greenhouse Gas Control, vol. 54, pp. 404-420, 2016.

[2] D. Zhuang, K. Ma, C. Tang, X. Cui, and G. Yang, "Study on crack formation and propagation in the galleries of the Dagangshan high arch dam in Southwest China based on microseismic monitoring and numerical simulation,"
International Journal of Rock Mechanics and Mining Sciences, vol. 115, pp. 157-172, 2019.

[3] C. Hammer, M. Ohrnberger, and D. Fäh, "Classifying seismic waveforms from scratch: a case study in the alpine environment," Geophysical Journal International, vol. 192, no. 1, pp. 425-439, 2013.

[4] B. Hassani, A. Yong, G. M. Atkinson, T. Feng, and L. Meng, "Comparison of site dominant frequency from earthquake and microseismic data in California," Bulletin of the Seismological Society of America, vol. 109, no. 3, pp. 1034-1040, 2019.

[5] S. Yaghmaei-Sabegh, "A novel approach for classification of earthquake ground-motion records," Journal of Seismology, vol. 21, no. 4, pp. 885-907, 2017.

[6] X. Liu, C. a. Tang, L. Li, P. Lv, and R. Sun, "Microseismic monitoring and stability analysis of the right bank slope at Dagangshan hydropower station after the initial impoundment," International Journal of Rock Mechanics and Mining Sciences, vol. 108, pp. 128-141, 2018.

[7] N. Xu, F. Dai, Z. Zhou, P. Jiang, and T. Zhao, "Microseismicity and its time-frequency characteristics of the left bank slope at the Jinping first-stage hydropower station during reservoir impoundment," Environmental Earth Sciences, vol. 75, 2016.

[8] V. Kumar, N. Gopalakrishnan, N. P. Singh, and S. Cherukuri, "Microseismic monitoring application for primary stability evaluation of the powerhouse of the Tapovan Vishnugad Hydropower Project," Journal of Earth System Science, vol. 128, 2019.

[9] X.-T. Feng, J. Liu, B. Chen, Y. Xiao, G. Feng, and F. Zhang, "Monitoring, warning, and control of rockburst in deep metal mines," Engineering, vol. 3, no. 4, pp. 538-545, 2017.

[10] J.-R. Zhou, T.-H. Yang, P.-H. Zhang, T. Xu, and J. Wei, "Formation process and mechanism of seepage channels around grout curtain from microseismic monitoring: a case study of Zhangmatun iron mine, China," Engineering Geology, vol. 226, pp. 301-315, 2017.

[11] F. De Santis, I. Contrucci, J. Kinscher, P. Bernard, V. Renaud, and Y. Gunzburger, "Impact of geological heterogeneities on induced-seismicity in a deep sublevel stoping mine," Pure and Applied Geophysics, vol. 176, no. 2, pp. 697-717, 2018.

[12] H. Hassani, F. Hloušek, C. Alexandrakis, and S. Buske, "Migration-based microseismic event location in the Schlema-Alberoda mining area," International Journal of Rock Mechanics and Mining Sciences, vol. 110, pp. 161-167, 2018.

[13] F. Liu, T. Ma, C. a. Tang, and F. Chen, "Prediction of rockburst in tunnels at the Jinping II hydropower station using microseismic monitoring technique," Tunnelling and Underground Space Technology, vol. 81, pp. 480-493, 2018.

[14] Z. Tang, X. Liu, Q. Xu, C. Li, and P. Qin, "Stability evaluation of deep-buried TBM construction tunnel based on microseismic monitoring technology," Tunnelling and Underground Space Technology, vol. 81, pp. 512-524, 2018.

[15] M. Li, M. Y. Ali, G. Tao, W. Alakberi, and H. Alnuaimi, "Monitoring of induced microseismicity in an onshore oilfield from Abu Dhabi, United Arab Emirates: implications for carbonate reservoir monitoring," Journal of Petroleum Science and Engineering, vol. 152, pp. 33-48, 2017.

[16] K. Ma, C. A. Tang, L. X. Wang et al., "Stability analysis of underground oil storage caverns by an integrated numerical and microseismic monitoring approach," Tunnelling and Underground Space Technology, vol. 54, pp. 81-91, 2016.

[17] G. Rodríguez-Pradilla and D. W. Eaton, "The application of coda and energy methods for magnitude estimation of 
microseismic events," Seismological Research Letters, vol. 90, pp. 1296-1307, 2019.

[18] A. L. Toussaint, R. Toussaint, F. K. Eriksen et al., "Source localization of microseismic emissions during pneumatic fracturing," Geophysical Research Letters, vol. 46, no. 7, pp. 3726-3733, 2019.

[19] P. K. Ghahfarokhi, T. H. Wilson, T. R. Carr, A. Kumar, R. Hammack, and H. Di, "Integrating distributed acoustic sensing, borehole 3C geophone array, and surface seismic array data to identify long-period long-duration seismic events during stimulation of a Marcellus Shale gas reservoir," Interpretation, vol. 7, no. 1, pp. SA1-SA10, 2019.

[20] C.-P. Lu, L.-M. Dou, N. Zhang et al., "Microseismic frequency-spectrum evolutionary rule of rockburst triggered by roof fall," International Journal of Rock Mechanics and Mining Sciences, vol. 64, pp. 6-16, 2013.

[21] J. Ning, J. Wang, L. Jiang, N. Jiang, X. Liu, and J. Jiang, "Fracture analysis of double-layer hard and thick roof and the controlling effect on strata behavior: a case study," Engineering Failure Analysis, vol. 81, pp. 117-134, 2017.

[22] J. Wang, J. Ning, P. Qiu, S. Yang, and H. Shang, "Microseismic monitoring and its precursory parameter of hard roof collapse in longwall faces: a case study," Geomechanics and Engineering, vol. 17, pp. 375-383, 2019.

[23] W. Zhang, X. Qu, C. Li et al., "Fracture analysis of multi-hard roofs based on microseismic monitoring and control techniques for induced rock burst: a case study," Arabian Journal of Geosciences, vol. 12, p. 784, 2019.

[24] J. He, L. Dou, S. Gong, J. Li, and Z. Ma, "Rock burst assessment and prediction by dynamic and static stress analysis based on micro-seismic monitoring," International Journal of Rock Mechanics and Mining Sciences, vol. 93, pp. 46-53, 2017.

[25] Z.-1. Li, X.-q. He, L.-m. Dou, and G.-f. Wang, "Rockburst occurrences and microseismicity in a longwall panel experiencing frequent rockbursts," Geosciences Journal, vol. 22, no. 4, pp. 623-639, 2018.

[26] M. R. Leake, W. J. Conrad, E. C. Westman, S. Ghaychi Afrouz, and R. J. Molka, "Microseismic monitoring and analysis of induced seismicity source mechanisms in a retreating room and pillar coal mine in the Eastern United States," Underground Space, vol. 2, no. 2, pp. 115-124, 2017.

[27] L. Jiang, Q. Wu, Q. Wu et al., "Fracture failure analysis of hard and thick key layer and its dynamic response characteristics," Engineering Failure Analysis, vol. 98, pp. 118-130, 2019.

[28] P. Wang, L. Jiang, J. Jiang, P. Zheng, and W. Li, "Strata behaviors and rock burst-inducing mechanism under the coupling effect of a hard, thick stratum and a normal fault," International Journal of Geomechanics, vol. 18, 2018.

[29] D. Mondal and P. N. S. Roy, "Fractal and seismic b-value study during dynamic roof displacements (roof fall and surface blasting) for enhancing safety in the longwall coal mines," Engineering Geology, vol. 253, pp. 184-204, 2019.

[30] C. Mark, "Coal bursts that occur during development: a rock mechanics enigma," International Journal of Mining Science and Technology, vol. 28, pp. 35-42, 2018.

[31] A. Keneti and B.-A. Sainsbury, "Review of published rockburst events and their contributing factors," Engineering Geology, vol. 246, pp. 361-373, 2018.

[32] B. Hebblewhite and J. Galvin, "A review of the geomechanics aspects of a double fatality coal burst at Austar Colliery in NSW, Australia in April 2014," International Journal of Mining Science and Technology, vol. 27, no. 1, pp. 3-7, 2017.

[33] X. Li, E. Wang, Z. Li, Z. Liu, D. Song, and L. Qiu, "Rock burst monitoring by integrated microseismic and electromagnetic radiation methods," Rock Mechanics and Rock Engineering, vol. 49, no. 11, pp. 4393-4406, 2016.

[34] P. Peng and L. Wang, "A nonparametric method for automatic denoising of microseismic data," Shock and Vibration, vol. 2018, pp. 1-8, 2018.

[35] S. M. Mousavi, C. A. Langston, and S. P. Horton, "Automatic microseismic denoising and onset detection using the synchrosqueezed continuous wavelet transform," Geophysics, vol. 81, no. 4, pp. V341-V355, 2016. 